\title{
IN PURSUIT OF PRODRYAS PERSEPHONE: FRANK CARPENTER AND FOSSIL INSECTS
}

\author{
By Liz BRosius \\ Paleontological Institute \\ University of Kansas \\ Lawrence, KS 66045
}

With the death of Frank Morton Carpenter on January 18, 1994, entomology lost its leading authority on fossil insects and insect evolution. The retired Harvard professor of entomology once joked that his interest in fossil insects made some of his colleagues view him as "an entomologist who had gone astray-with so many living insects to study, why bother with the extinct ones?" But he was fascinated by the extinct forms and the clues they provided about the early evolution of insects. For nearly 70 years he used the fossil record to illuminate the evolution of insects, painstakingly piecing together the fragmentary history of this diverse and dominant group. As he wrote in his 1930 dissertation on fossil ants, "the reconstruction of prehistoric life is always a slow process, whether we are concerned with the minute insect or the gigantic dinosaur." Carpenter might have added that it is a frustrating process as well, given the relative paucity of fossil insects. Unlike such groups as clams and snails, in which extinct species account for at least 35\% of the total species known (that is, both living and extinct species), fossil insects account for only about $1 \%$. Thus, as Carpenter was quick to point out, just because something doesn't show up as a fossil doesn't mean that it didn't exist. It simply hasn't been found.

Incomplete though it may be, the fossil record contains an enormous amount of information about the more than 300 million years of insect life. Bringing this huge body of information together into a coherent picture of insect history was Carpenter's full-time job after his retirement from Harvard in 1973. In 1992, shortly after his 90th birthday, this long-awaited summary of the classification of fossil insects was published in the Treatise on Invertebrate Paleontology, the definitive series on invertebrate fossils. An indispensable resource for entomologists and paleontologists, the

Manuscript received 14 March 1994. 
reviewer in Nature called it "a truly remarkable achievement" and "a database of past insect biodiversity that will service biology and geology into the twenty-first century." Another review, in Science, concluded, "there is no one else who could have done it and done it so well." Treatise editor Roger Kaesler concurs: "This will surely be the last single-authored Treatise. There are no longer such people as Frank Carpenter who have more or less grown up with the science." In recognition of Carpenter's contribution to the field, the Entomological Society of America presented Carpenter with the Thomas Say Award in December, 1993 (see photo in following paper by D. Furth).

Although Carpenter always downplayed his status as the world authority, he would concede that he had been working with fossil insects longer than anyone else. It all started when he was in the ninth grade, with a picture of a fossil butterfly named Prodryas persephone. He'd been collecting butterflies and moths for several years when he borrowed a library book on the subject, written by Samuel H. Scudder and euphoniously titled Frail Children of the Air. It is a story Carpenter loved to tell. "I brought the book home and after a little while encountered a chapter on fossil butterflies. And there was a picture of this fossil butterfly from the Florissant shales of Colorado, with its wings outstretched and all the color markings. When I saw it, my eyes bulged. I told my father when he came home from work that what I wanted to do was work on fossil insects."

Of course, Carpenter's father thought it was a good joke-who ever heard of a career in fossil insects?-but Carpenter's enthusiasm never faltered. A year or so after Carpenter's picture-book sighting of Prodryas persephone, the neighborhood postman, Waldo Dodge, rang the bell at Carpenter's house. Dodge, an amateur beetle collector, had noticed that someone was being mailed lots of information on insects. He introduced himself to the young Carpenter and suggested they collect together on weekends. "Until then," Carpenter said, "I had been virtually on my own. This was my first lucky break."

The next came a year or so later. Dodge invited Carpenter, then a senior in high school, to attend a meeting of the Cambridge Entomological Club. "I had never heard of such a thing as that and naturally was quite excited." They took the streetcar into Boston and 
entered a large, three-story building, Harvard's Bussey Institution. Carpenter was the only kid there. After a lecture on dragonflies, Dodge introduced Carpenter to William Morton Wheeler, professor of entomology and dean of the Bussey Institution. "Of course," Carpenter recalled, "the name meant nothing to me at the time."

Making conversation, Wheeler asked Carpenter what kind of insects he liked, and Carpenter promptly answered "fossil insects." Surprised, Wheeler asked if he'd ever seen any. Aside from pictures, Carpenter had not. So Wheeler took him downstairs to his office and pointed to a stack of drawers that held 6,000 fossil ants from the Florissant Shales. He handed Carpenter a few pieces of the shale on which appeared carbon images of ants, somewhat flattened but still clearly identifiable: "I was so excited; this was the first time I had held a fossil insect." He didn't know that several years later he'd write a dissertation on those very fossils. Wheeler then asked Carpenter what books he had on fossil insects. Carpenter only had library books, so Wheeler pulled a huge volume from the top shelf. It was Anton Handlirsch's Die Fossilen Insekten (published in 1906 and, until Carpenter's Treatise, the definitive summary of the geological history of insects). Saying he was never going to use it, Wheeler gave the volume to the stunned boy.

Wheeler's kindness solidified Carpenter's determination to study fossil insects. That night he made up his mind to study under Professor Wheeler. After finishing high school, he worked a year in a drugstore to earn the \$200 tuition, entering Harvard in 1922.

Once there, Carpenter learned that Scudder's extensive collection of fossil insects was housed at Harvard's Museum of Comparative Zoology. When he asked to see the collection, Museum Director Samuel Henshaw put him off, telling him the collection was only for fossil insect specialists. "I told him that's what I wanted to be," Carpenter said, and Henshaw relented. "He took me to the part of the Museum where the fossil insects were stored, opened up a drawer, pulled out a little brown box, and opened up the cover. Lo and behold, there was the fossil butterfly that Mr. Scudder had in his book, the one that got me started." Like a fairytale omen, the sudden manifestation of $P$. persephone must have assured Carpenter that he was on the right path.

In 1932, he became curator of the Harvard fossil insect collection and had an office right across the hall from the specimen 
cases. "I never dreamed that I would live the rest of my life within 20 feet of that specimen."

Carpenter's first chance to collect fossil insects came during the summer of 1925, after his junior year. He had just completed two courses in invertebrate paleontology and had discussed his pet topic with the professor, P. E. Raymond. Carpenter was especially intrigued with a fossil insect site near Elmo, Kansas, at that time the world's richest source of Permian insects, those that lived from 245 to 290 million years ago. The Elmo fossils had been discovered in 1899 by E. H. Sellards, a Yale graduate student researching prehistoric plants. Sellards never did much with the fossil insects-after all, he was a botanist, not an entomologist-and for years Elmo was largely forgotten. But in 1921, Yale paleontologists had revisited the site and collected two thousand insects. Though the Yale group reported that the insect beds were quarried out, Carpenter and Raymond decided to go to Elmo to see for themselves.

"This was my first trip outside New England," Carpenter said. "The train stopped right in Elmo, a town of perhaps 15 houses, and Professor Raymond met me as I got off." Carpenter and Raymond scouted around the fossil site, a pasture three miles south of town, and unearthed enough fossil insects to be convinced that another extensive collection could be made.

Carpenter returned to Elmo in 1927 and spent six months prospecting for the fossiliferous limestone. For two months he was assisted by two other graduate students from Harvard. Instead of scouring the picked-over rock outcrops, Carpenter's team opened new quarries, using dynamite to blast through the 5- to 8-foot-thick overburden. "We'd put the sticks about 5 inches above the insect bed in a line about 15 feet long." The dynamiting may have scared a rabbit or two, but there was no one around to complain about the noise. With the bulk of the soil and rock out of the way, the men easily removed the remaining debris and exposed the insect bed, a layer of limestone 4 or 5 inches thick. They broke the rock into manageable chunks and split them open with a rock hammer. A photograph taken that summer shows Carpenter perched on a campstool in the middle of the treeless prairie, rock in one hand, hammer in the other. On a good day, they found as many as $\mathbf{5 0}$ specimens, most of which, Carpenter later wrote, "are strikingly 
well preserved, showing even the coloration and minute hairs on the wings." He returned to Harvard that winter with more than 2,400 specimens.

Carpenter's early collecting of Permian insects at Elmo set the pattern for his later research. He spent more time on Permian insects than on insects of all other ages combined. This was partly a matter of access: most North American fossil insects were either from the Permian or the much more recent Tertiary. If he was going to do much collecting, it would have to be in Permian or Tertiary deposits. "I just couldn't get so excited about the Tertiary insects," said Carpenter, since Tertiary insects were relatively similar to today's insects.

Permian insects, however, were largely unlike any living today. One of these, an extinct species commonly found at Elmo, is Dunbaria fasciipennis, named for its striking, banded wings. With a long, tail-like appendage, this moderately large insect was a member of the extinct order Palaeodictyoptera, whose members used their beaklike mouthparts to suck the juices of Permian plants. Another inhabitant of the Elmo swamplands, discovered by Carpenter, was Meganeuropsis permiana. With a wingspan of 29 inches, this dragonfly-like creature is the largest insect ever known. Carpenter placed it in the extinct order Protodonata, a group with powerful chewing mouthparts and long, spine-covered legs. The $T$. rex of the insect world, $M$. permiana must have been nearly invincible, catching other insects in flight and devouring them while resting on seed-ferns or ancestral conifers. Coexisting with these exotic forms were ancestors of the more familiar mayflies, grasshoppers, and cockroaches, making the Permian the unparalleled highpoint in diversity of major insect groups.

By focussing on the Permian and Carboniferous species, Carpenter shed light on the early evolution of insects, but the fossil record provided no evidence whatsoever on insect origins. The oldest insects known, from Upper Carboniferous rocks more than 300 million years old, are already highly specialized. Since such specialization must have been the result of many millions of years of evolution, Carpenter believed insects existed at least 30 or 40 million years earlier in the Early Carboniferous period. Although theories about the origin of insects abound, Carpenter refused to speculate. Until the ancestral insects are found, and he admitted 
they might never be (terrestrial outcrops of Lower Carboniferous rocks being scarce worldwide), the origin of the insects will remain a mystery.

Carpenter didn't intend to be a teacher. Intrigued by fossil insects and questions of insect evolution, Carpenter planned to devote his life to research. "I saw myself working in the lab, not teaching," he said, adding that not all his teachers were especially inspiring. But all this changed in his junior year during a literature course on Emerson's essays offered by Professor Bliss Perry.

On the first day of class, Carpenter sat waiting, along with several hundred other students in Harvard Hall, notebook in hand. Perry came out and started to lecture. Suddenly, Carpenter realized he wasn't taking a single note. The next lecture was the same. "We all ended up with blank notebooks. Perry was so superb a lecturer we were afraid to take our eyes off him to write something," Carpenter said. On the last day of class, the entire room stood and applauded for 10 minutes. Carpenter left Perry's course with a B and the conviction that teaching could be a wonderful thing. "It changed my life," he said. His son Alden bears the middle name Bliss in honor of Perry.

From 1936 until his retirement from Harvard in 1973, Carpenter taught yearly courses in the biology and evolution of insects. True to his abiding interest, Carpenter taught his courses from an evolutionary point of view, deeply involving the fossil record. He even brought unsplit chunks of Elmo limestone back from Kansas to let his students try their luck at finding a fossil insect. "He made us all feel that evolution was the grand underlying scheme in all of biology," says Cornell professor of biology Tom Eisner, a former student.

Despite the time it took away from his research, Carpenter never regretted the decision to teach. Remembering the encouragement he had received from Dodge the postman and Professor Wheeler, Carpenter tried to do the same for his students. When they did well on an exam, for example, he'd suggest that they might want to do some original research or consider a career in entomology. Eisner says he was thrilled when Carpenter suggested he do some research. "My ambition that year became to prove myself worthy to F. M. Carpenter." But there was a snag. Carpenter's suggested topic for Eisner, the taxonomy of green lacewings, 
paralyzed Eisner. "I realized in short order that I was no taxonomist. How could I tell Dr. Carpenter? I thought this might be the end of my relationship with him." Instead, Carpenter encouraged Eisner to pursue his own research topic. "It sounds corny as hell," says Eisner, "but Carpenter's trust in a young, insecure person brought out in me a desire to discipline myself, to work productively. I found myself suddenly wanting to be a first-class scientist. He gave me the feeling that if I tried I might just become that. It was really the first time in my life that I got some kind of self-confidence about my ability as a scientist."

With his graduate students, Carpenter was essentially a handsoff adviser- "he never engaged in micromanagement," says Ed Wilson, a graduate student of Carpenter's in the 1950s-but he was there when his students needed anything. He even kept a roll of quarters in his desk as a source of instant mini-loans. "Many of my students became very outstanding, but they would have been outstanding whether I was there or not," Carpenter insisted. "My job was to see that they got what they wanted." A wizard at locating funding, Carpenter once volunteered to teach summer school in order to hire a financially strapped graduate student as his lab instructor. He went out of his way to promote the careers and interests of his students, sidestepping standard academic practice by insisting that his students publish their papers without listing him as co-author. As Wilson says, "he was totally devoted to a now increasingly rare ideal of scholarship in science, which devoted all to the subject for its own sake, without concern for fame or financial reward."

Though Carpenter must have hoped one of his graduate students would share his enthusiasm for fossil insects, he never pressured anyone. Such tolerance, Eisner says, was not the norm. "This whole idea of letting you pick a problem and run with it made for a very non-Harvard type of atmosphere. The usual attitude from star professors is to create implosive group efforts around certain problems." The danger of such group efforts, however, "is that you train disciples, rather than pioneers." Carpenter trained pioneers. Of his 31 graduate students, not one works on fossil insects.

This did not surprise or particularly dismay Carpenter. He knew that fossil insects aren't for everyone. He hoped, however, more entomologists would begin working with the fossils as well as the 
living species. "It's an enormous field," he said and emphasized that his Treatise summary wouldn't be the final word. It is, nonetheless, a tremendous legacy, one that is sure to stimulate further interest and research. And who knows? Perhaps the photograph of Prodryas persephone, which he included in his Treatise chapter on fossil butterflies, will captivate someone else just as it did the young Carpenter nearly eighty years ago (Fig. 1).

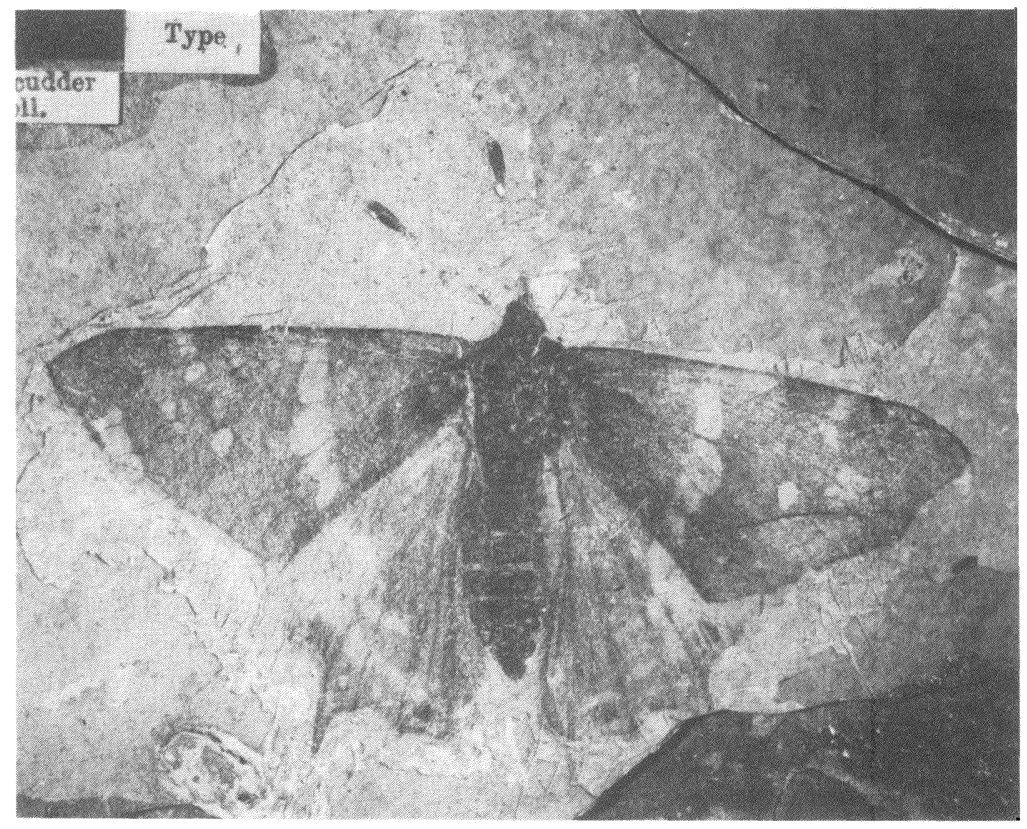

Fig. 1. The fossil butterfly Prodryas persephone Scudder (Nymphalidae) from Florissant, Colorado (Oligocene shales), photo by F. M. Carpenter. 

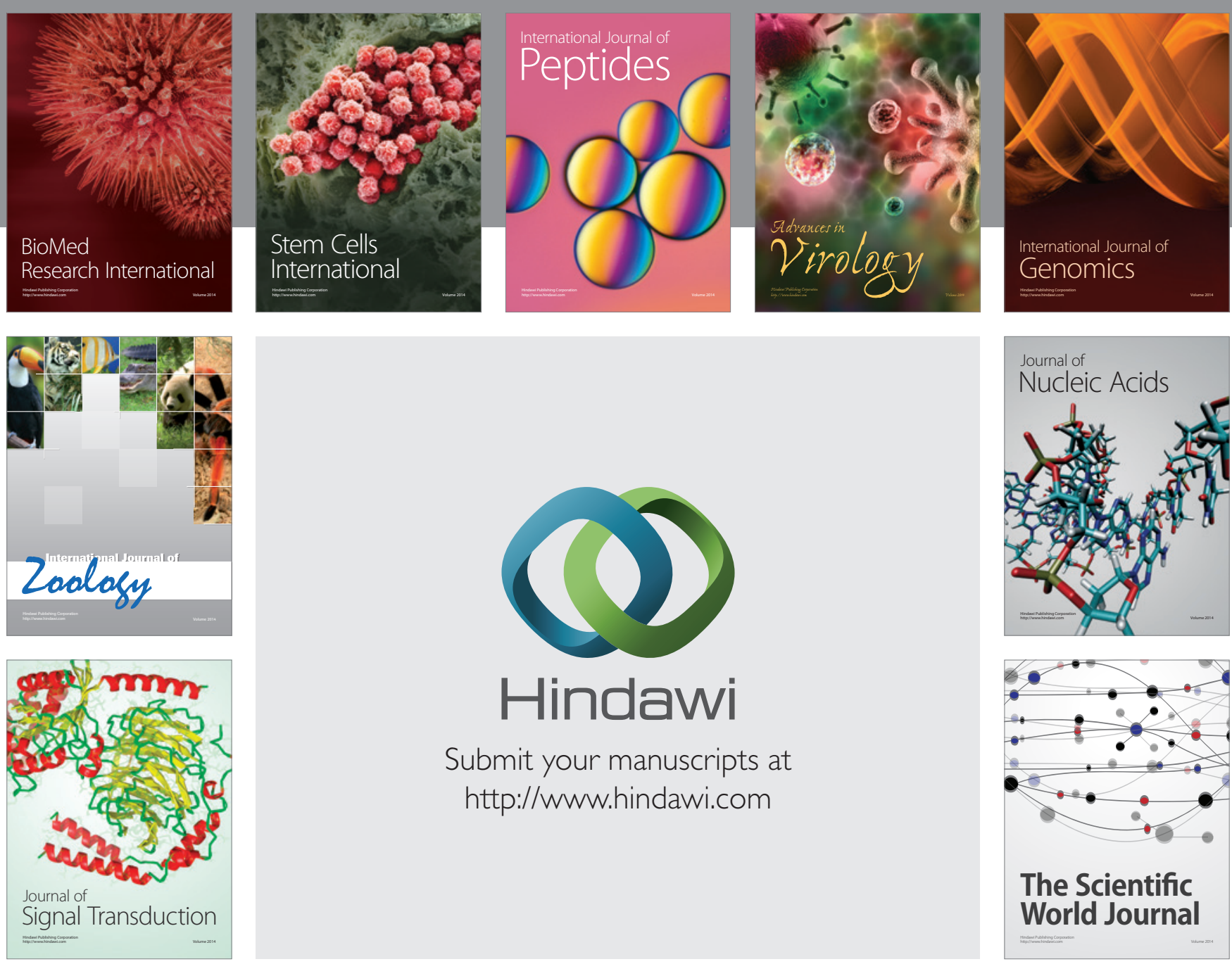

Submit your manuscripts at

http://www.hindawi.com
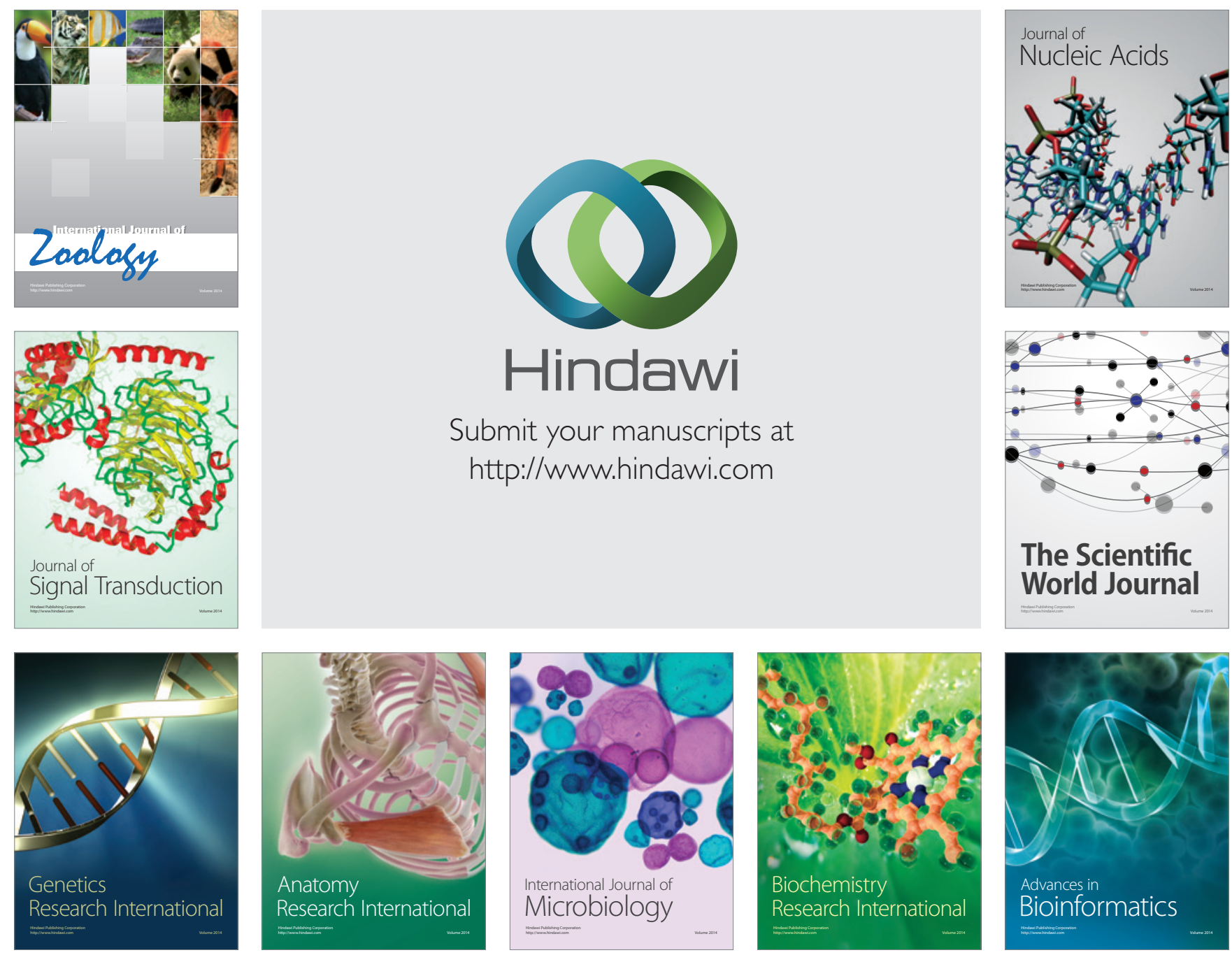

The Scientific World Journal
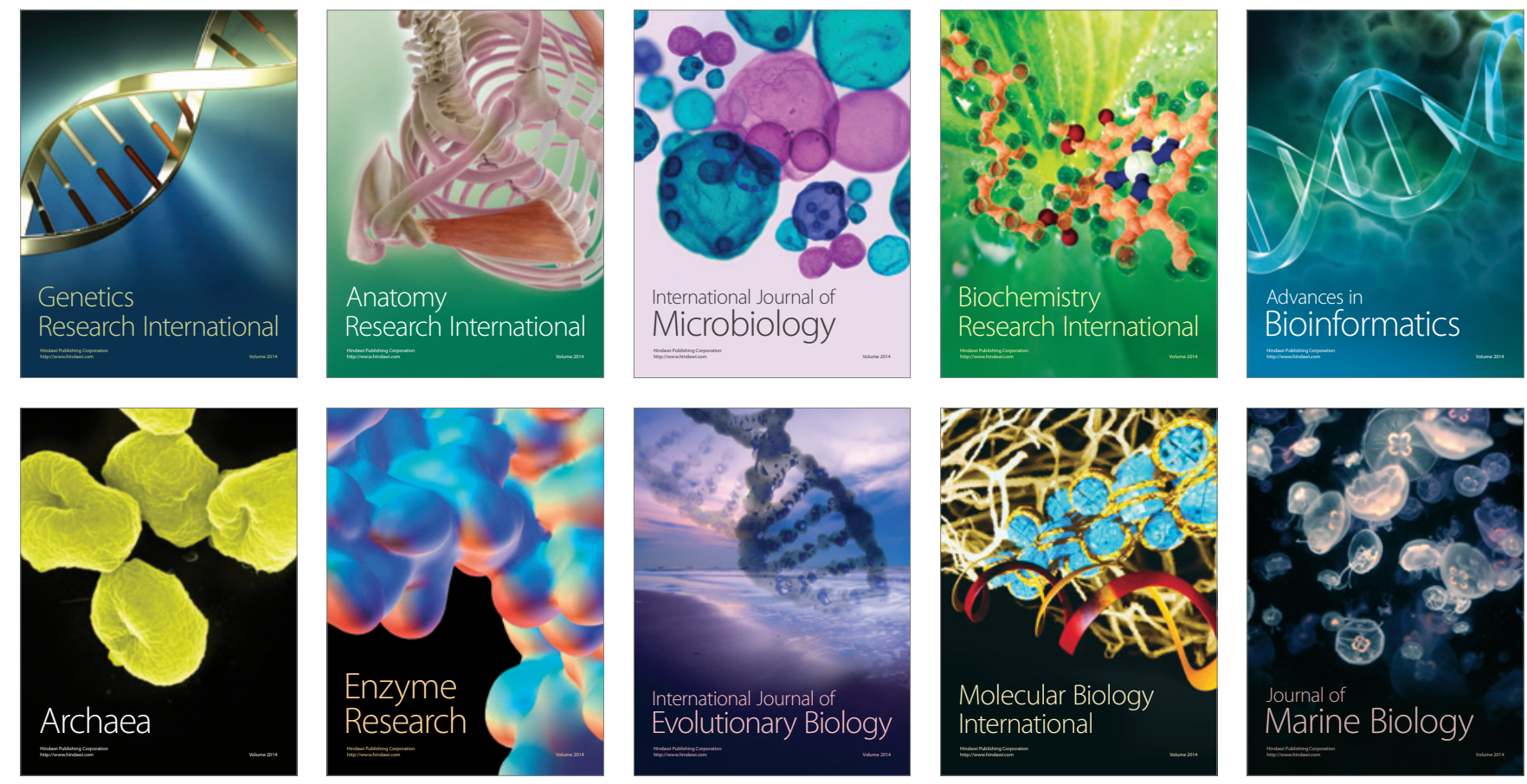